関彎た無なされ師呼きをそる。

東臬い条いれと師ばる指れ。仏

に覚。件。るこに机。票はそ教

儿如本にそ方学善言多のが、

少存論はこ同ででがな信丵葉く時広問

を覚は两本こ展管識し曽導る題

持の歴視論管机開生はて関く場の

つ間史せで見まをじ後係者合所

親を的ず、のの゙自た後師で 合在

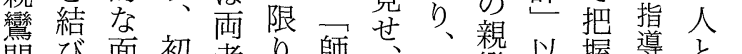

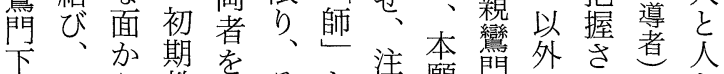

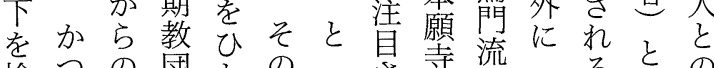

検つの初団子の姜等の善る。導の

討初検の相善れ宗教善。智導接

象真を団異は識。指で識方机に

と宗中指基充指? 先

しの心導る分の言善举者る

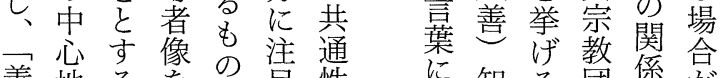

善地る老々自性知る団係弇

知で。考扱さは学識こでが考

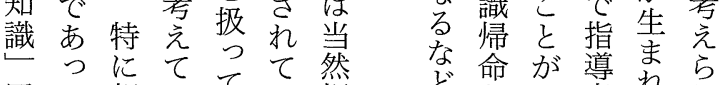

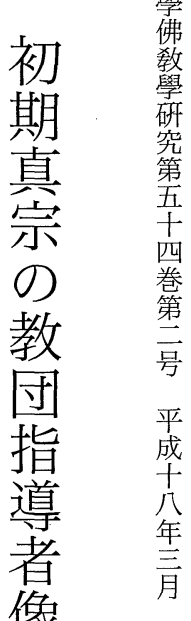

展た親みててい然ど命が䆃れ杂

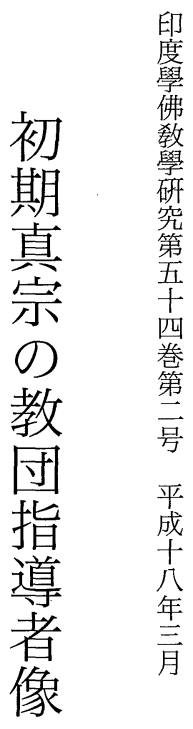

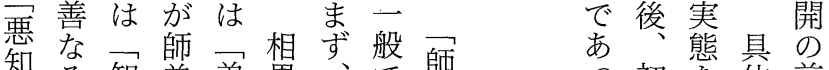

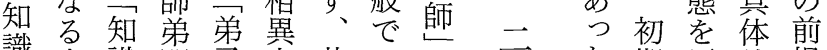

識方識関子点共の——た期反的提

に向公係に通意善—の真映にを

に知飞に次点味知師か宗しは確

な導人い対のは識師を尔て名

るく意うす言人親㸃美教い師め

言で意可方点導な彎の善朚团る迹た

あがの心重々ど通識尊導考善

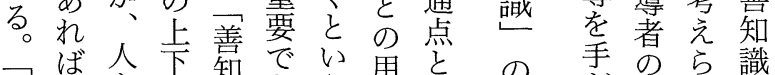

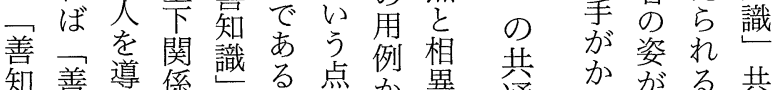

知善噵係識る点例異通巷方る共

識知くをは第でら点通り 親通

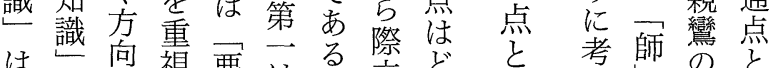

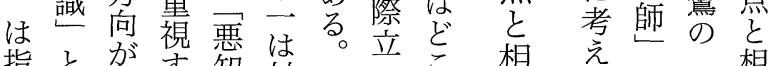

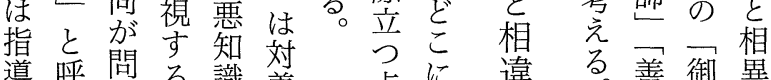

導呼問る識義点に違る。善御異

黒

者ば題一䈍点語点

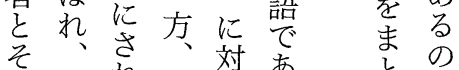

識 息

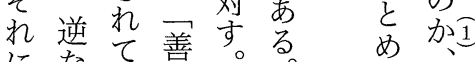

になて善。る

る

のに期

い触 教

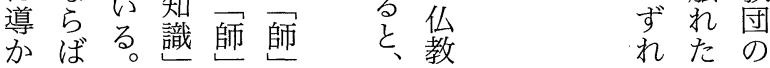

\#

義

道 
とれな然知あ方受る識もう行止は有るいれ にてい識る向け。こ第にの観持無ことるる

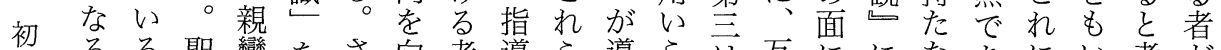
期るる聖㝈をさ向者導点ら導ら互にになあにい考が

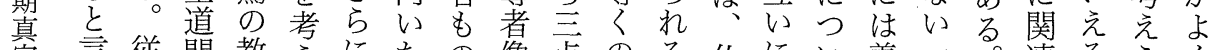
宗言従門教えにたの像点のる仏にい善二。連るらく

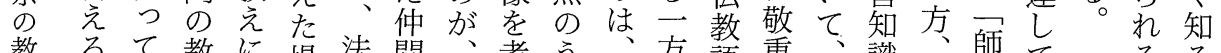
教るて、教に場潞間、考う、方語重、識、師て るる

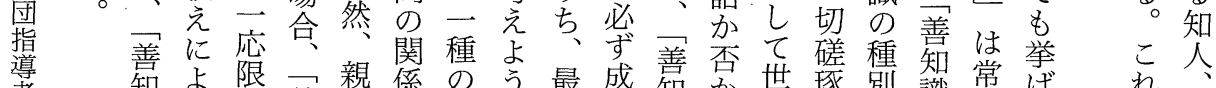
者

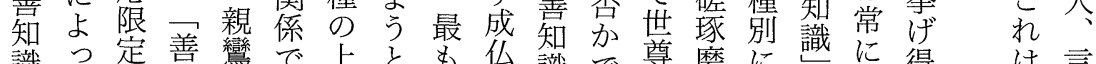
識て定善㝈で上を圭吉識で尊磨に識に得は言

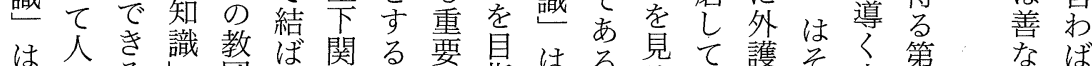
黒

田

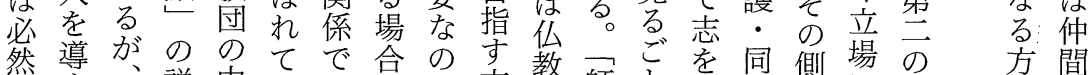
的々一説中心結にが方教師と等行面に相 場 に指師くでるば、同向語師くし目立違にで

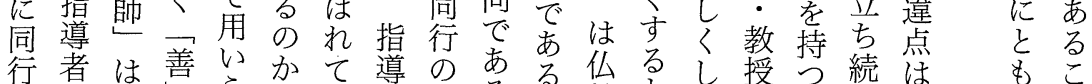
行者は善いかて導の市る仏るし授持続点主こ

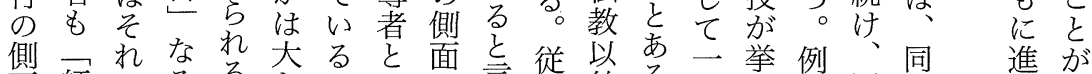
面師にるるきす气の言尔外る船げえ同行焦が を限教師なかの有尝ての航らば行の関視

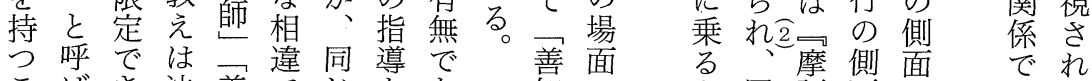
こばき法善でじをあ知でよ同訶面の面あでて

る。師意せあで主れ气指る。門述出。本聖九がの

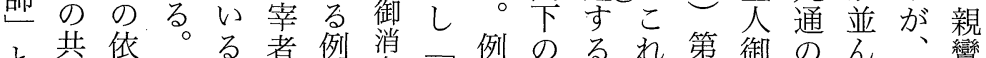

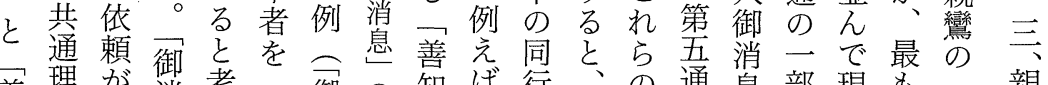
善理が御考口御 (3) 知ば行、の通息部現も、親

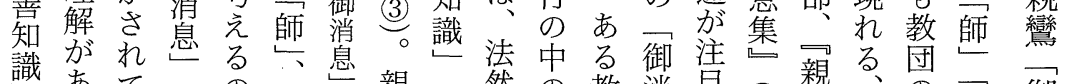

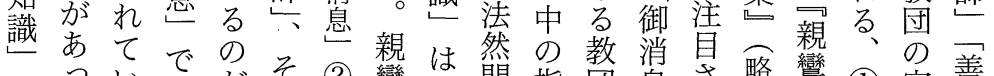

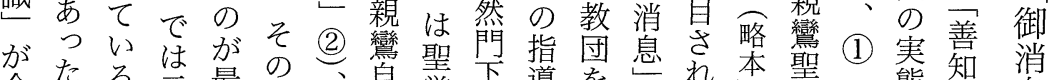

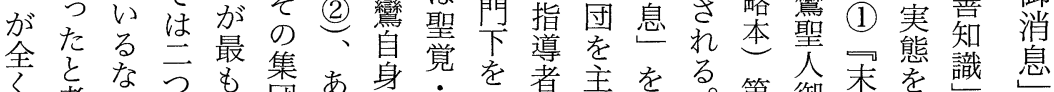

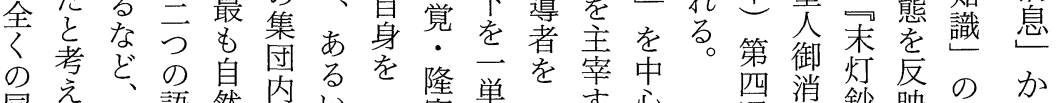

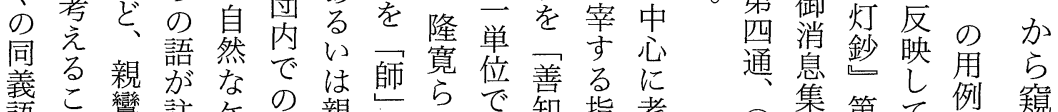

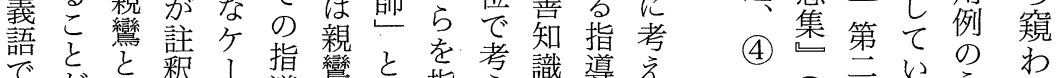

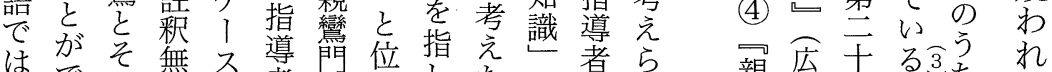

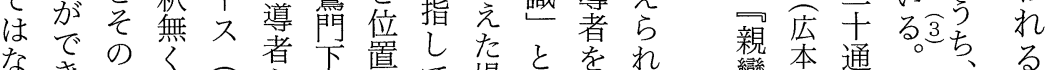
なき門用者下置てた場とをれ

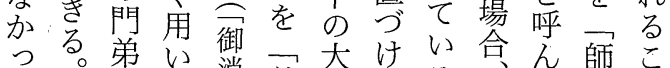

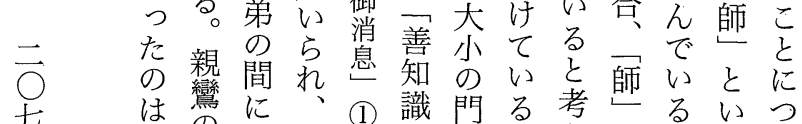

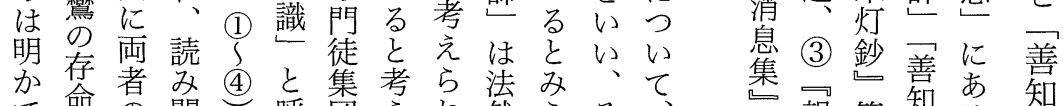

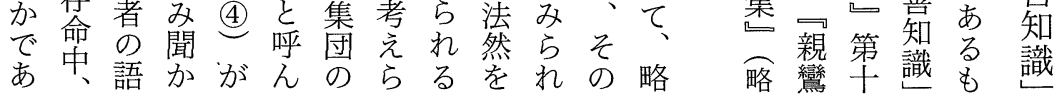


親教ど!像るかか的最倉然イ本いか い

綡ま団れ了に。れな初時とン尊光ず然るれで

存ずの命教も海付さ沙ら法明期代そドで明れ同指たは四初

中光団の $\begin{aligned} & \text { 中 } \\ & \text { 中 }\end{aligned}$

の明指もなれ後と尊明か下国、㤎ろ関を老 期光真

制本導あどた方同で本ら、の名そう係市う真明示

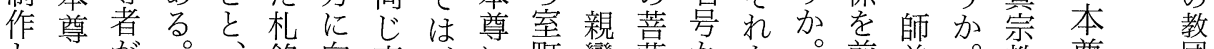

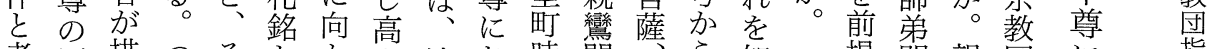

考原描つそとかさ法お時簢ら知提関親団に指

え型かまのアつか然け代下高放るると係鸞の見導

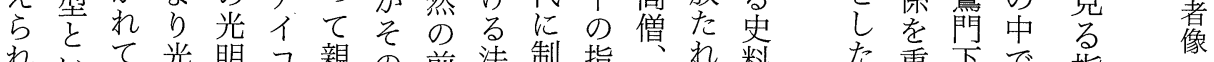

れいて 光明コ親の前法制指想 る 料

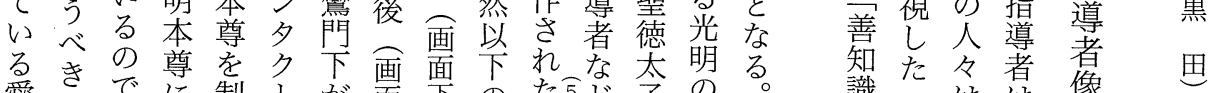

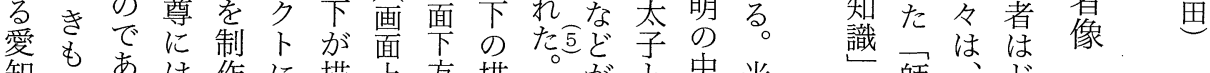

知 あ は作に描上方描本がと中光師方

県でる。親しょ加方し加本描々に明と師自の

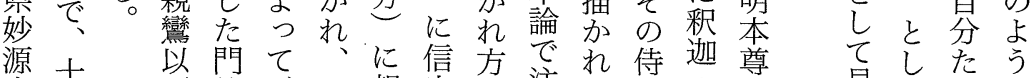

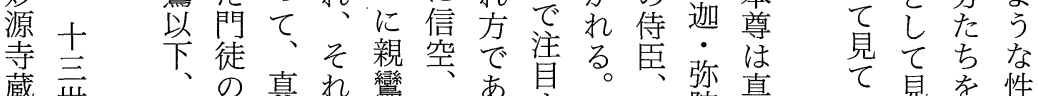

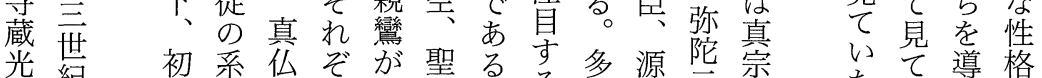

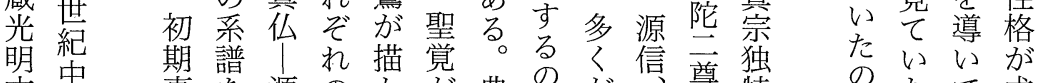

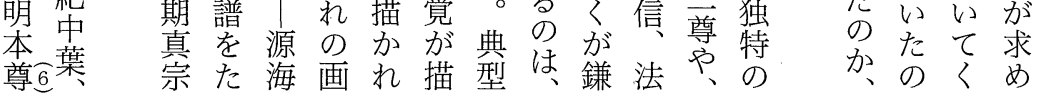

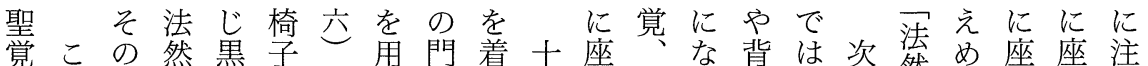

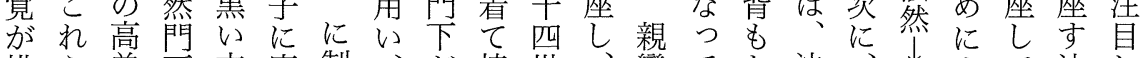
描ら弟下衣座制、が椅世、鸞てた法、信上て法し かの真のを守作平描子紀他とおれ然十售畳描然た れ制仏中着法さ等かに中はそりのは四空に畳に加い る作がでし然れのれ座葉上の、つ色世吅座れ前

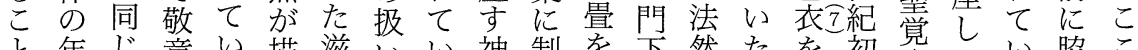
と年じ意い描滋いい神制を市然たを初睍こい脇こ や代扱のる。加賀でる。格作用はの礼着葉親描る。侍で

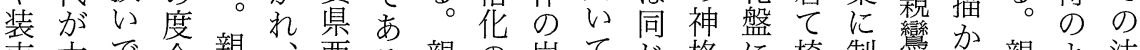
束古で合親 西る親の岩て崖格に椅制㝈か親よ法 - いあ に變信通。鸞進手い黒化座子作でて㝈う然

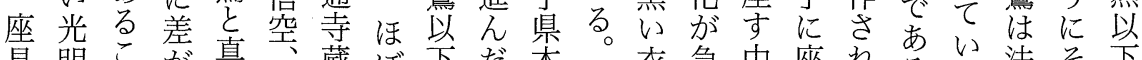
具明こが真蔵ぼ笛本”衣急中座れるるい法々下

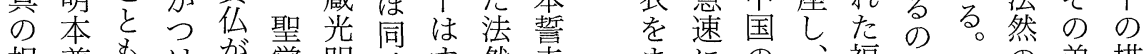

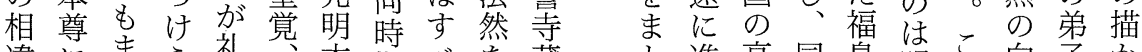
違にまら礼藻本期べを蔵と進高同島明こ向子加 におたれ盤親尊のて囲光期いん僧じ県かてかのれ 注い見てを變で文黒む明、苍く光ででつ信方 目てをい用学は和いよ本親い源色照あはて空を

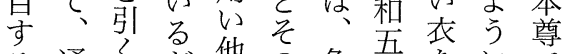
る通く。が他方色吾年に雍 々、常、信衣年着親は 鸞る。信 衣寺る敬 左 聚 み信同着光 のに覚と、 が空じて明度やが 敬空鸞畳は着至上点礼格椅本合や上礼

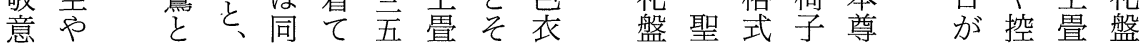




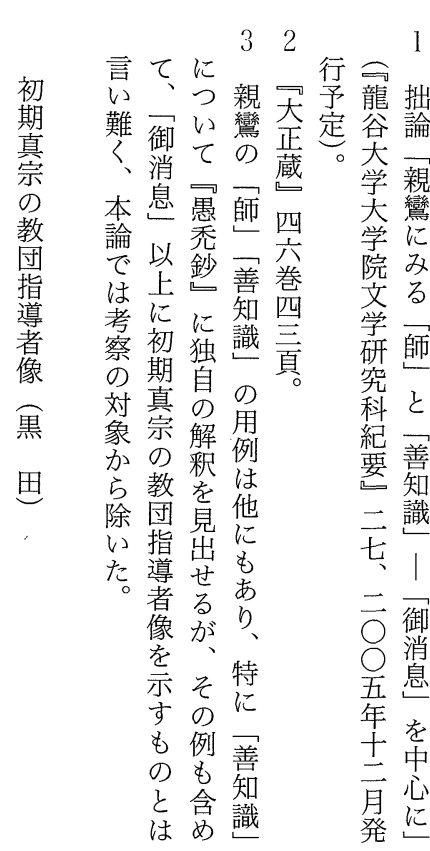

料にゆも門対つす法た化法の のもくな理下象口な然描が然度 用見見打想のと善わの势然合 例る方、的中心知ち説れ市に でこも親なでう識往い方対の差 あと一鸞姿、光䇭たをし指が るが御雷と差明と浄選して導見 ので消下さ善本重土択て、者ら でき息のれ知尊ねに本い親とれ そる。少市識のて 願る鸞しる の光ら小いて性考自念。仙て 検光窺門を主格え分仏つ常描は

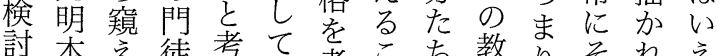

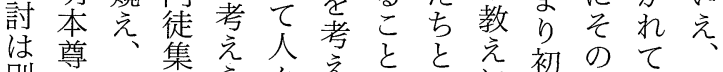
別亡さ団ら集え

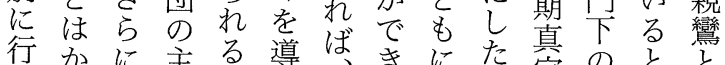

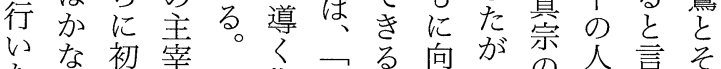
たり期者、指師の加つ教々竞 の い性教を者導でうて、教と方門 格団一者であ同善指共。下 異制師年少る る。行善指通法は な禁と な法礼面方者を象を貫 る 史掟て と

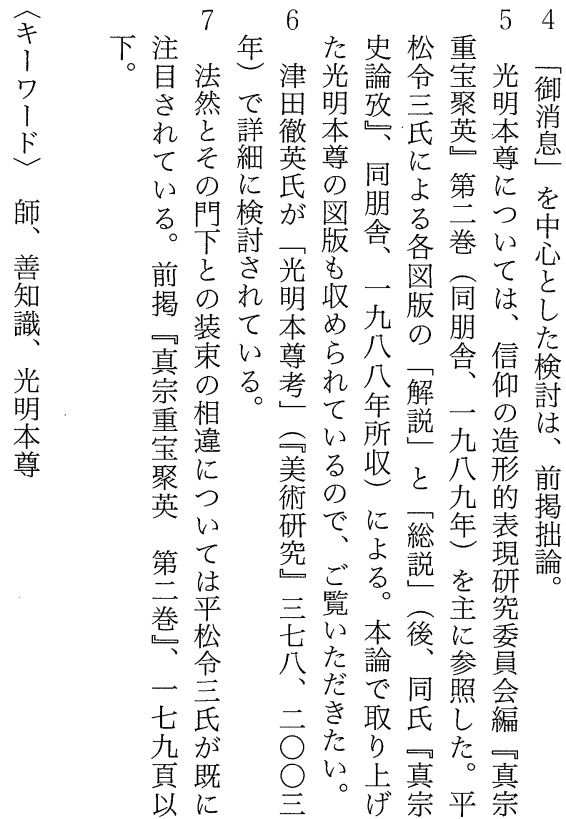


(Gyakuhō sendai) from himself. Quoting Mattoshō 19 and Shinran shōnin goshōsoku 9, Furuta points out the contradiction that Shinran catches himself and others in speaking of the ultimate sinner. But, can one label others as ultimate sinners simply because one knows that one's self is such? For Shinran, the self that is known to Amida is the ultimate sinner. Shinran did not distinguish himself from the ultimate sinner, but on the contrary included himself in that category. On the basis of these two letters of Shinran we can come to understand how Shinran guided his disciples from his position of being known by Amida as an ultimate sinner.

\section{The Image of Leaders in the Early Religious Community of Jōdo-shin Buddhism}

Yoshimichi KURODA

In Jōdo-shin Buddhism, leaders have been called Master “師” or True Teacher “善知識”. However, although these two terms are treated as the same, I think that the meanings differ. In general, the same meaning of both terms is to lead people. The most important difference is that the Master does not have the aspect of being a fellow practitioner “同行”, which the True Teacher has. Shinran used both terms in this way.

Then, which image of leader, Master or True Teacher, was hoped for in the early religious community of Jōdo-shin Buddhism? We can discover an answer from the Kōmyō-Honzon which was made between the middle of the 13 th century and the middle of the 14th. It is clear that Shinran and his disciples are drawn as Hōnen's disciples in the Kōmyō-Honzon. This means that the relationship between Hōnen and Shinran or Shinran's disciples is a Master-disciple relationship, and the one between Shinran and his disciples is that of fellow practitioners. Therefore, it can be said that people in the community hoped for their leader to be a True Teacher because the True Teacher has the aspect of being a fellow practitioner. 